International Journal of Business Management and Economic Review

Vol. 4, No. 04; 2021

ISSN: 2581-4664

\title{
THE EFFECT OF REGIONAL MANAGEMENT INFORMATION SYSTEM AND CASH MANAGEMENT SYSTEM ON NAGAN RAYA DISTRICT GOVERNMENT WORK UNIT PERFORMANCE WITH EMPLOYEE PERFORMANCE AS A MEDIATION VARIABLE
}

\author{
Ricky Ramadhan, Said Musnadi and Nadirsyah \\ Management Department, Universitas Syiah Kuala, Indonesia \\ http://doi.org/10.35409/IJBMER.2021.3304
}

\begin{abstract}
This study aims to determine the effect of the Regional Management Information System (SIMDA) and Cash Management System (CMS) on the performance of the Nagan Raya District Government Work Unit (SKPK Nagan Raya) through employees' performance. The population in this study was all employees of 48 SKPK Nagan Raya consisting of 3 agencies, 19 services, 1 inspectorate, 10 sub-district offices, 1 Civil Service Policy (PP) and WH office, 7 secretariats, 1 Study Activity Center (SKB) education office and 3 Departmental Technical Implementing Unit (UPTD) with a total population of employees as many as 3627 people. The research sample was determined based on the number of estimated indicators, which was at least 5-10 times the number of indicators. Based on the estimation, a sample size of $22 \times 5=110$ was obtained. The result reveals that SIMDA, CMS, Employee Performance and SKPK Nagan Raya Performance are not at the good levels, SIMDA affects employee performance, CMS affects employee performance, SIMDA affects SKPK Nagan Raya performance, CMS affects SKPK Nagan Raya employee performance, employee performance affects SKPK Nagan Raya performance, SIMDA affects SKPK Nagan Raya performance through employee performance, and CMS affects SKPK Nagan Raya employee performance through employee performance. In the research model, employee performance is also proved to act as the partial mediator. These findings mean that it has been proven that this model can be used as a model for improving organizational performance, especially in SKPK Nagan Raya. Academically this research model contributes to science which reveals that the role of Management Information Systems which in this study uses SIMDA as a unique subject, as well as CMS, are very capable of influencing employee performance and impacting organizational performance/SKPK Nagan Raya. In the future, further researchers can use this research model as the main basis in developing their research by adding other variables such as training and development as well as organizational culture.
\end{abstract}

Keyword: MIS, CMS, Employee Performance, Organizational Performance.

\section{INTRODUCTION}

The role, function, and performance of district government institutions in Indonesia, or known as District Government Work Unit (SKPK), now become an actual issue in determining the direction of progress and welfare of people's lives in various regions in Indonesia, especially in the second level areas which are still being blocked by various problems in various fields of 


\section{International Journal of Business Management and Economic Review}

Vol. 4, No. 04; 2021

ISSN: 2581-4664

development, including in Nagan Raya District. Facing the complexity and dynamics of current government tasks, the SKPK in Nagan Raya district (SKPK Nagan Raya) are required to be able to achieve budget realization targets that are effective, efficient, beneficial, and have a better impact on the community. This effort certainly requires support from the better performance of the State Civil Apparatus.

However, the performance of employees in some SKPKs in Nagan Raya has problems that need to be solved considering that the realization of the budget for them has not been achieved optimally. This condition is related to various factors, including the information system factor, namely the Regional Management Information System (SIMDA), and the Cash Management System (CMS). The SIMDA application is an application developed by the Indonesia Financial and Development Supervisory Agency (BPKP) to accelerate the process of reforming regional financial management. The application aims to assist the local governments in managing regional finances in an integrated manner, starting from budgeting, administration, accounting, and reporting (Hartono, 2013). This condition will improve SKPK's performance in realizing budget realization that is right on target, useful, and gives a better impact on the community.

The implementation of the SIMDA as a system has also improved the administrator's role in decision-making. Financial Administration Officers (PPK), Expenditure Treasurers, and Technical Activities Management Officers (PPTK) as end-users of the SIMDA Application will have sufficient information to complete various tasks that are increasingly urgent and meet the priority scale. Then CMS or known as non-cash transactions is also one of the factors that influence the performance of employees in SKPKs in the Nagan Raya district. CMS is a transaction that does not make payments in cash but by transferring books or transfers between accounts. The application of non-cash transactions can facilitate the process of financial accountability in regional financial management.

\section{LITERATURE REVIEW}

\section{The Influence of Management Information System on Organizational Performance}

A good management information system is a supporter of the success of organizational goals. The main task of Management Information System (MIS) in the organization is as a feedback flow, MIS as a means of completing plans, and at the same time as a monitoring tool by comparing the results of the realization of the plan with the standards that have been set (Tyoso, 2016). The utilization of information technology, internal control systems, and the application of regional financial accounting systems have a significant positive influence on the performance of government institutions (Djalil, Nadirsyah, Yahya, Jalaluddin, \& Ramadhanti, 2017). Management information can effectively improve organizational performance (Imran, Darwanis, \& Arfan, 2014). Furthermore (Imran et al., 2014) provided recommendations that the use of management information systems effectively can improve organizational performance.

\section{The Influence of Cash Management System on Organizational Performance}

The cash management system (CMS) is a government strategy to prevent corruption, with the main responsible parties they are the Ministry of Finance, Ministry of Home Affairs, and Ministry of Law and Human Rights. This system also involves Bank Indonesia (Indonesia Central Bank), the Supreme Audit Agency, the Financial Services Authority, the Center for 
International Journal of Business Management and Economic Review

Vol. 4, No. 04; 2021

ISSN: 2581-4664

Financial Transaction Reports and Analysis, the Government Goods/Services Procurement Policy Institute, the Financial and Development Supervisory Agency, and the Regional Government.

Information systems and technology are used by organizations to collect, analyze, and present information more quickly and competently which is certainly related to all operations and duties of employees in the organization. The performance will be determined by the extent of the system and technology applied (Sudriman et al., 2020). The utilization of CMS can improve institutional performance (Juliansyah, 2017). The application of CMS has an effect on improving government performance (Sari, 2020).

\section{The Influence of Management Information System on Employee Performance}

Management information systems can form a coordinated and organized work system so as to form the character of human resources who have quality (Sudriman et al., 2020). Regional information systems have a significant impact on employee performance (Pirade, Saleh, \& Amar, 2013). Information technology partially or simultaneously affects managerial performance (Gurendrawati, Murdayanti, \& Putri, 2014). (Lasmaya, 2016) and (Jean, Sinkovics, \& Kim, 2008) found that human resources (HR) information systems have a significant impact on improving employee performance.

\section{The Influence of Cash Management System on Employees Performance}

The CMS is a government strategy to prevent and eradicate corruption, as those in charge of this strategy are the Ministry of Finance, the Ministry of Home Affairs, and the Ministry of Law and Human Rights. The agencies involved are Bank Indonesia, the Supreme Audit Agency, the Financial Services Authority, the Center for Financial Transaction Reports and Analysis, the Government Goods/Services Procurement Policy Institute, the Financial and Development Supervisory Agency, and the Regional Government (Sari, 2020). The utilization of CMS can improve the performance of institutions (Juliansyah, 2017).

\section{The Influence Of Employee Performance On Organizational Performance}

Every employee in the organization is required to make a positive contribution through good performance, reminding that organizational performance depends on the performance of its employees (Gibson, Ivancevich, Donnelly, \& Konopaske, 2012). Employee performance affects the performance of the inspectorate in the Nagan Raya District (Fahmi, Musnadi, \& Nadirsyah, 2019).

\section{The Influence of Management Information System on Organizational Performance through Employee Performance}

The main function of a management information system is to increase knowledge and reduce user uncertainty. In complex activities, information can only increase user certainty or reduce various choices that often make mistakes and the length of time for making work decisions (Sutabri, 2012: 24). The management information system is one of the instruments in facilitating the management in carrying out the functions of planning, organizing, moving, and supervising so that organizational productivity will be better (Sudriman et al., 2020). The use of 
International Journal of Business Management and Economic Review

Vol. 4, No. 04; 2021

ISSN: 2581-4664

information systems can improve employee performance (knowledge workers) so that they can optimize organizational goals and performance (Laudon \& Laudon, 2014).

\section{The Influence of Cash Management System on SKPD Performance through Employee Performance}

The use of CMS can improve the performance of institutions (Juliansyah, 2017). The application of CMS has a simultaneous effect on improving government performance (Sari, 2020). Thus, the use of an easier and measurable system will have a good impact on organizations, especially public organizations. The relationship of the influence of cash management practices with business performance (Gulet, 2014).

\section{Theoretical Framework and Research Hypothesis}

Based on the theoretical basis put forward by previous experts, a research model framework can be formulated as shown in Figure 1.

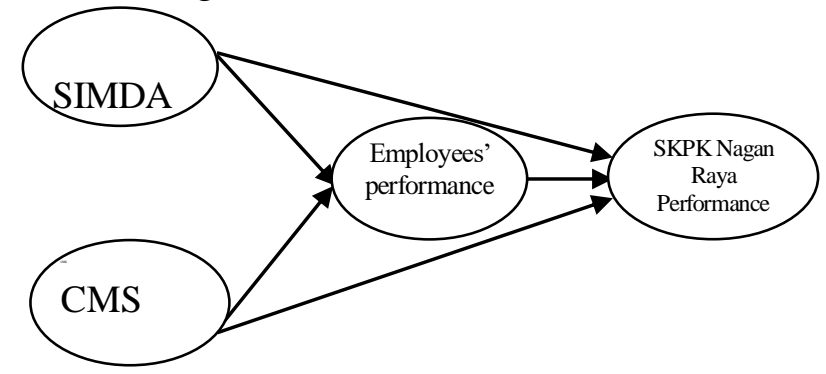

Figure 1. Theoretical Framework

Also, the research hypotheses that can be formulated for this research are as follows.

H1 : SIMDA, CMS, Employee Performance, and SKPK Nagan Raya Performance are at good levels.

$\mathrm{H} 2$ : SIMDA affects employee performance

H3 : CMS affects employee performance

H4 : SIMDA affects SKPK Nagan Raya performance

H5 : CMS affects SKPK Nagan Raya employee performance

H6 : employee performance affects SKPK Nagan Raya performance

H7 : SIMDA affects SKPK Nagan Raya performance through employee performance

H8 : CMS affects SKPK Nagan Raya employee performance through employee performance

\section{RESEARCH METHOD}

\section{Population and Sample}

The population in this study was all employees of 48 Nagan Raya District Government Work Unit (SKPK Nagan Raya), consisting of 3 agencies, 19 offices, 1 inspectorate, 10 subdistrict offices, 1 Civil Sercive Policy (PP) and WH office, 7 secretariats, Study Activity Center (SKB) education office and 3 UPTDs. The number of employees was 3627 people.

The research sample was determined based on the number of estimated sample indicators revealed by Hair et al (2014) which is at least 5-10 times the number of indicators. Based on the 
International Journal of Business Management and Economic Review

Vol. 4, No. 04; 2021

ISSN: 2581-4664

number of indicators used in this study, the estimated sample is $22 \times 5=110$.

Operational Variable

Table 1. Operational Variable

\begin{tabular}{|c|c|c|c|c|}
\hline Nc & o Variable & Indicators & \multirow[t]{2}{*}{ Instruments } & \multirow[t]{2}{*}{ Scale } \\
\hline & Endogenous & & & \\
\hline 1 & Organization performance $(\mathrm{Y})$ & $\begin{array}{ll}\text { 1. } & \text { Productivity } \\
\text { 2. } & \text { Service Quality } \\
\text { 3. } & \text { Responsivity } \\
\text { 4. } & \text { Responsibility } \\
\text { 5. } & \text { Accountability } \\
\text { 6. } & \text { Efficiency } \\
\text { 7. } & \text { Effectiveness } \\
\text { 8. } & \text { Justice } \\
\text { (Dwiyanto, 2012) }\end{array}$ & Questionnaire & Likert \\
\hline & Mediation & & & \\
\hline & $\begin{array}{l}\text { Employee Performance } \\
\text { (Z) }\end{array}$ & $\begin{array}{ll}\text { 1. } & \text { Service orientation } \\
\text { 2. } & \text { Commitment } \\
\text { 3. } & \text { Discipline } \\
\text { 4. } & \text { Cooperation } \\
\text { 5. } & \text { Leadership } \\
\text { (Reg. } & \text { No.30/2019) }\end{array}$ & Questionnaire & Likert \\
\hline & Exogenous & & & \\
\hline 2 & $\begin{array}{l}\text { Regional Management } \\
\text { Information Systems }\left(\mathrm{X}_{1}\right)\end{array}$ & $\begin{array}{ll}\text { 1. } & \text { Accurate } \\
\text { 2. } & \text { On-time } \\
\text { 3. } & \text { Relevant } \\
\text { 4. } & \text { Enough } \\
5 . & \text { Minimize costs } \\
\text { (Al-gharaibeh \& } \quad \text { Malkawi, } \\
\text { 2013) }\end{array}$ & Questionnaire & Likert \\
\hline 3 & Cash management system $\left(\mathrm{X}_{2}\right)$ & $\begin{array}{ll}\text { 1. } & \text { Income collection } \\
\text { 2. } & \text { Shopping expenses } \\
\text { 3. } & \text { Receipt of fees } \\
\text { 4. } & \text { Financing expenses } \\
\text { (Mahmudi, 2013) }\end{array}$ & Questionnaire & Likert \\
\hline
\end{tabular}

\section{Data Analysis Tool}

To examine the effect of the Regional Management Information System (SIMDA) and Cash Management System (CMS) on the performance of District Working Service Units, a Structural Equation Modeling (SEM) analysis model was used with the support of the AMOS application system. 
International Journal of Business Management and Economic Review

Vol. 4, No. 04; 2021

ISSN: 2581-4664

\section{RESULT}

\section{Descriptive Hypothesis (H1)}

Descriptive hypothesis testing was carried out using a one-sample test with a cut-off value of 3.41 and a significance value of $<0.05$. The test results are as follows:

Table 2. One-Sample T-Test

\begin{tabular}{|c|c|c|c|c|c|c|}
\hline & \multicolumn{6}{|c|}{ Test Value $=3.41$} \\
\hline & \multirow[t]{2}{*}{$T$} & \multirow[t]{2}{*}{ Df } & \multirow{2}{*}{$\begin{array}{l}\text { Sig. } \\
(2- \\
\text { tailed) }\end{array}$} & \multirow{2}{*}{$\begin{array}{l}\text { Mean } \\
\text { Difference }\end{array}$} & \multicolumn{2}{|c|}{$\begin{array}{l}95 \% \text { Confidence Interval of } \\
\text { the Difference }\end{array}$} \\
\hline & & & & & Lower & Upper \\
\hline SIMDA & 36,530 & 149 &, 000 & 11,96333 & 11,3162 & 12,6105 \\
\hline CMS & 36,875 & 149 &, 000 & 9,37667 & 8,8742 & 9,8791 \\
\hline Employee Performance & 46,073 & 149 &, 000 & 13,21000 & 12,6434 & 13,7766 \\
\hline $\begin{array}{l}\text { SKPK Nagan } \\
\text { Performance }\end{array}$ & Raya 48,170 & 149 &, 000 & 22,55667 & 21,6314 & 23,4820 \\
\hline
\end{tabular}

From the table above, it can be seen that the significance level of all of them is below 0.05 so it can be stated that the performance of SKPK, employee performance, cash management system (CSM), and regional management information system (SIMDA) in Nagan Raya district has not been running well. So the hypothesis 1 result test accepts $\mathrm{H} 1$ and rejects $\mathrm{H} 0$.

\section{Measurement Model Test with Confirmatory Factor Analysis}

Confirmatory factor analysis (CFA) is used to test whether a construct has unidimensionality or whether the indicators used to confirm the research variable construct really have appropriateness, usefulness, and validity that lead to the accuracy of interpretation of data measurements. The contribution of the CFA value of each indicator is said to be valid if it is obtained a value of $>0.50$. Invalid indicators cannot determine the accuracy of hypothesis testing so that these indicators must be eliminated from the research model because they can affect the goodness of fit model and others (Hair, Babin, Anderson, \& Black, 2018) 
International Journal of Business Management and Economic Review

Vol. 4, No. 04; 2021

ISSN: 2581-4664

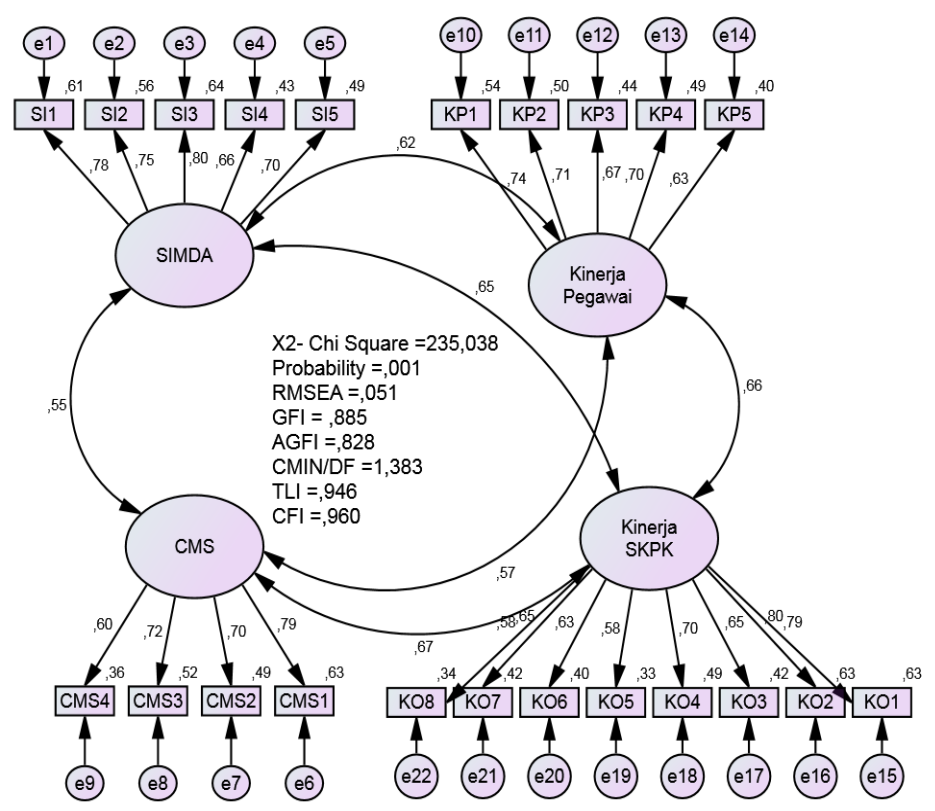

Figure 2. Measurement Model Test Result

Table 3. Standardized Regression Weights

\begin{tabular}{|c|c|c|c|c|}
\hline Indikator & & Variabel & Estimate & $\begin{array}{l}\text { Signifikansi } \\
\text { Cut Of }\end{array}$ \\
\hline SI1 & $<--$ & SIMDA & 0.784 & 0.000 \\
\hline SI2 & $<--$ & SIMDA & 0.746 & 0.000 \\
\hline SI3 & $<--$ & SIMDA & 0.802 & 0.000 \\
\hline SI4 & $<--$ & SIMDA & 0.656 & 0.000 \\
\hline SI5 & <--- & SIMDA & 0.701 & 0.000 \\
\hline CMS1 & $<---$ & CMS & 0.794 & 0.000 \\
\hline CMS2 & $<--$ & CMS & 0.698 & 0.000 \\
\hline CMS3 & $<--$ & CMS & 0.719 & 0.000 \\
\hline CMS4 & $<--$ & CMS & 0.598 & 0.000 \\
\hline KP1 & $<---$ & Employees' performance & 0.736 & 0,000 \\
\hline KP2 & $<--$ & Employees' performance & 0.710 & 0.000 \\
\hline KP3 & <--- & Employees' performance & 0.667 & 0.000 \\
\hline KP4 & $<---$ & Employees' performance & 0.702 & 0.000 \\
\hline KP5 & $<--$ & Employees' performance & 0.632 & 0.000 \\
\hline KO1 & $<--$ & SKPK & 0.793 & 0.000 \\
\hline
\end{tabular}




\section{International Journal of Business Management and Economic Review}

Vol. 4, No. 04; 2021

ISSN: 2581-4664

\begin{tabular}{|l|lrl|l|l|}
\hline \hline Indikator & & \multicolumn{2}{|l|}{ Variabel } & Estimate & $\begin{array}{l}\text { Signifikansi } \\
\text { Cut Of }\end{array}$ \\
\hline & & \multicolumn{2}{|l|}{ Performance } & & \\
\hline KO2 & $<--$ & $\begin{array}{l}\text { SKPK Nagan Raya } \\
\text { Performance }\end{array}$ & 0.796 & 0.000 \\
\hline KO3 & $<--$ & $\begin{array}{l}\text { SKPK Nagan Raya } \\
\text { Performance }\end{array}$ & 0.650 & 0.000 \\
\hline KO4 & $<--$ & $\begin{array}{l}\text { SKPK Nagan Raya } \\
\text { Performance }\end{array}$ & 0.698 & 0.000 \\
\hline KO5 & $<---$ & $\begin{array}{l}\text { SKPK Nagan Raya } \\
\text { Performance }\end{array}$ & 0.579 & 0.000 \\
\hline KO6 & $<---$ & $\begin{array}{l}\text { SKPK Nagan Raya } \\
\text { Performance }\end{array}$ & 0.630 & 0.000 \\
\hline KO7 & $<---$ & $\begin{array}{l}\text { SKPK Nagan Raya } \\
\text { Performance }\end{array}$ & 0.650 & 0.000 \\
\hline KO8 & $<---$ & $\begin{array}{l}\text { SKPK Nagan Raya } \\
\text { Performance }\end{array}$ & 0.584 & 0.000 \\
\hline
\end{tabular}

Table 3 above proves the indicators of SI1 and SI5 are used to confirm the construct of the Regional Management Information (SIMDA) variable, indicators of CSI1 and CSI4 are used to confirm the construct of the Cash management system (CMS) variable, indicators of KO1 and KO8 are used to confirm the construct of the SKPK Nagan Raya performance variable, and the indicators of KP1 and KP5 are used to confirm the construct of the employee performance variable. All measurement results are declared valid because the loading value is above 0.5 and the regression weight significance value is below the limit of 0.05 .

\section{Conformity Test of Goodness of Fit}

The use of the SEM model through AMOS computation requires the fulfillment of a fit analytical model that can be proven by comparing the model fit indices (goodness of fit) with the critical value (cut-off value) as shown in the following table.

Table 4. The goodness of Fit Criteria

\begin{tabular}{|l|l|l|l|}
\hline The goodness of Fit Index & Cut off Value & Result & Evidence \\
\hline $\mathrm{X}^{2}$ - Chi-Square & 201.423 & 182.508 & Fit Model \\
Significance Probability & $\geq 0.05$ & 0.141 & Fit Model \\
RMSEA & $\leq 0.08$ & 0.028 & Fit Model \\
GFI & $\geq 0.90$ & 0.907 & Fit Model \\
AGFI & $\geq 0.90$ & 0.856 & Not Fit \\
CMIN/DF & $\leq 2.00$ & 1.120 & Fit Model \\
TLI & $\geq 0.95$ & 0.983 & Fit Model \\
CFI & $\geq 0.95$ & 0.988 & Fit Model \\
\hline
\end{tabular}


International Journal of Business Management and Economic Review

Vol. 4, No. 04; 2021

ISSN: 2581-4664

Based on the results of the SEM model test shown in the table above, it is known that the chi-square value is 182.508 or less than 201.423 . With a probability value of 0.141 or greater than 0.05 . Furthermore, the RMSEA value is obtained at 0.028 or below 0.08 . The GFI value is 0.907 and the AGFI is 0.856 or each > 0.90 . The CMINDF value is 1.120 or below 2. The TLI value is 0.983 and the CFI is 0.988 , both are more than 0.95 . Thus, it can be stated that the overall model in this study has met the assumption of the goodness of fit model.

\section{Structure Model Test (H2, H3, H4, H5, and H6)}

The quality relationship developed in the hypothesis can be proven through a structural model. Structural models explain the existence of a real relationship between the construct of latent variables or exogenous variables with endogenous variables at a certain level of error (significant) or where the relationship between these variables is really real (significant). The structural analysis model can be seen as follows:

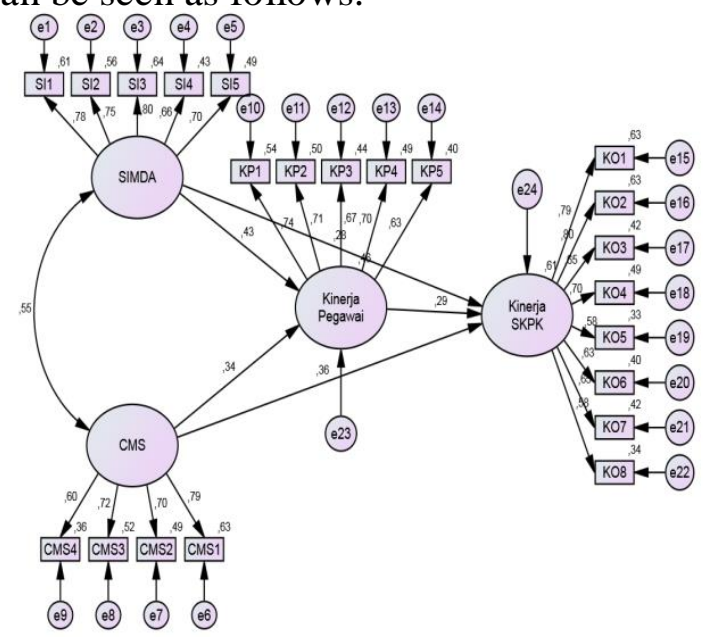

Figure 3. Structural Model Test Result

Direct Effect Hypothesis Test

There are 5 (five) direct hypotheses to be tested in this study, regarding the influence of SIMDA and CMS on employee performance and SKPK Nagan Raya performance. The results of direct hypothesis testing can be seen in the following figure and table.

Table 5. Direct Effect Hypothesis Test Results

\begin{tabular}{|l|l|l|l|l|l|}
\hline Endogen & Exogen & $\begin{array}{l}\text { Standardized } \\
\text { Estimate }\end{array}$ & S.E. \\
\hline Employees' performance & $<-$ & SIMDA & 0.431 & $0.0973 .906 * * *$ \\
\hline Employees' performance & - & - & CMS & 0.337 & 0.0943 .052
\end{tabular}


International Journal of Business Management and Economic Review

Vol. 4, No. 04; 2021

ISSN: 2581-4664

\begin{tabular}{|c|c|c|c|}
\hline Endogen & xogen & $\begin{array}{l}\text { Standardized } \\
\text { Estimate } \\
\end{array}$ & S.E. ${ }^{\text {C.R }} \mathbf{P}$ \\
\hline \begin{tabular}{|l|l} 
SKPK Nagan Raya \\
Performance
\end{tabular} & SIMDA & p.279 & $0.115 . .752 \frac{2.00}{p}$ \\
\hline \begin{tabular}{|l|} 
SKPK Nagan Raya \\
Performance
\end{tabular} & CMS & 0.355 & $0.1123 .4655^{* * *}$ \\
\hline \begin{tabular}{|l|l|} 
SKPK Nagan Raya \\
Performance
\end{tabular} & \begin{tabular}{l|l}
$<-$ & Employees' \\
- & performance \\
\end{tabular} & p.286 & $0.139 .652^{2} .00$ \\
\hline
\end{tabular}

H2: The Effect of SIMDA on Employee Performance

The test result of the SIMDA effect on employee performance shows a Critical Ratio (C.R) value of $\mathbf{3 . 9 0 6}$ or greater than $\mathbf{1 . 9 6}$ and a significant p-value at a level of 0.000 or less than 0.05 . Thus, SIMDA has a positive and significant influence on employee performance. The magnitude of the influence of SIMDA on employee performance is 0.431 . This value can be interpreted that every $1 \%$ increase in SIMDA functions and capabilities will be able to increase employee performance by $0.431 \%$.

\section{H3 : The Effect of CMS on Employee Performance}

The test result of the CMS effect on employee performance shows a Critical Ratio (C.R) value of 3.052 or greater than $\mathbf{1 . 9 6}$ and a significant $p$-value at a level of 0.002 or less than 0.05 . Thus, CMS has a positive and significant impact on employee performance. The magnitude of the effect of CMS on employee performance is $\mathbf{0 . 3 3 7}$. This value can be interpreted that every $1 \%$ increase in the function and ability of the CMS will be able to increase employee performance by $\mathbf{0 . 3 3 7 \%}$.

H4 : The Effect of SIMDA on SKPK Nagan Raya Performance

The test result of the SIMDA effect on SKPK Nagan Raya performance shows a Critical Ratio (CR) value of $\mathbf{2 . 7 5 2}$ or greater than $\mathbf{1 . 9 6}$ and a significant p-value at a level of 0.006 or less than 0.05 . Thus, SIMDA has a positive and significant impact on the performance of the SKPK. The magnitude of the influence of SIMDA on employee performance is $\mathbf{0 . 3 1 7}$. This value can be interpreted as every $1 \%$ increase in the function and ability of SIMDA will be able to increase the performance of SKPK by $\mathbf{0 . 3 1 7 \%}$.

H5 : Effect of CMS on SKPK Nagan Raya Performance

The test result of the CMS effect on SKPK Nagan Raya performance shows a Critical Ratio (C.R) value of $\mathbf{3 . 4 6 5}$ or greater than $\mathbf{1 . 9 6}$ and a significant p-value at a level of 0.000 or less than 0.05. Thus, CMS has a positive and significant impact on the performance of the SKPK. The magnitude of the effect of CMS on the performance of SKPK is $\mathbf{0 . 3 5 5}$. This value can be interpreted that every $1 \%$ increase in the function and ability of the CMS will be able to increase the performance of the SKPK by $\mathbf{0 . 3 3 5 \%}$.

H6 : The influence of employee performance on SKPK Nagan Raya performance

The results of testing employee performance on SKPK Nagan Raya performance show a 


\section{International Journal of Business Management and Economic Review}

Vol. 4, No. 04; 2021

ISSN: 2581-4664

Critical Ratio (C.R) value of 2.652, greater than 1.96, and a significant p-value at a level of 0.008 less than 0.05 . Thus, it can be stated that employee performance has a positive and significant influence on SKPK Nagan Raya performance. The magnitude of the influence of employee performance on the performance of SKPK is 0.286 . These results can be interpreted that every $1 \%$ increase in employee performance will affect the performance of SKPK by $0.286 \%$. This result supports the research conducted by (Fahmi et al., 2019) stating that employee performance affects the performance of the inspectorate in Nagan Raya

Indirect Effect Hypothesis Test

There are 2 (two) indirect effect hypotheses tested in this study using Sobel test analysis are the SIMDA effect on SKPK Nagan Raya performance through employee performance and CMS effect on SKPK Nagan Raya performance through employee performance. The results of indirect hypothesis testing can be explained as follows.

H7: The Effect of SIMDA on SKPK Nagan Raya Performance through Employee Performance

Based on the Sobel test calculation engine, the significant value for the indirect influence of SIMDA on SKPK Nagan Raya performance through employee performance can be seen in the following figure:

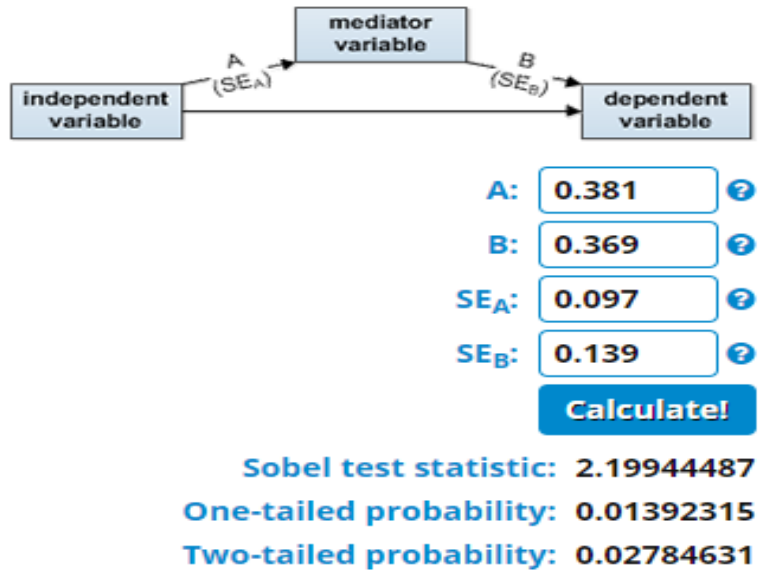

Figure 4. Mediation Effect Test Result of H7

The results of the Sobel Test calculation show that the Sobel test statistic value of SIMDA's influence on SKPK Nagan Raya performance through employee performance is 2.199. This value is greater than 1.96 and is at a significant two-tailed probability value of 0.02 or less than 0.05 . This influence is strengthened by the estimated mediation value of $0.431 \times 0.286=$ 0.123 . This means that employee performance can significantly mediate the effect of SIMDA on SKPK Nagan Raya performance by $0.123 \%$. In this model, the employee performance is also proved acting as the partial mediator.

H8: The Effect of CMS on SKPK Nagan Raya Performance through Employee Performance Based on the Sobel test calculation, the significant value for the indirect influence of CMS 
International Journal of Business Management and Economic Review

Vol. 4, No. 04; 2021

ISSN: 2581-4664

on SKPK Nagan Raya performance through employee performance can be seen in the following figure:

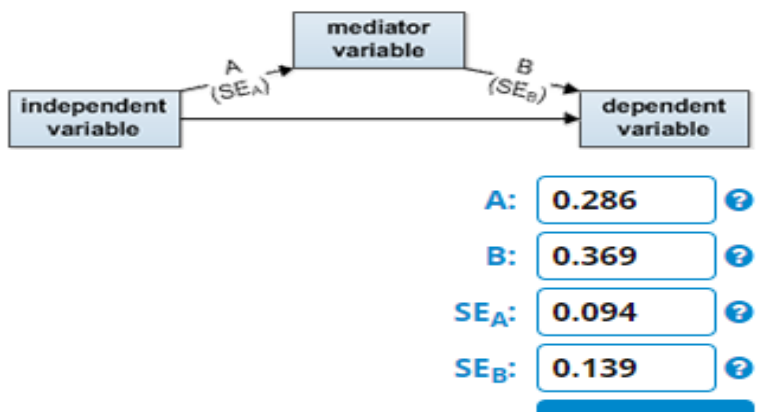

CalculateI

Sobel test statistic: $\mathbf{2 . 0 0 0 3 0 7 9 3}$

One-tailed probability: $\mathbf{0 . 0 2 2 7 3 3 5 1}$

Two-tailed probability: 0.04546702

Figure 5. Mediation Effect Test Result of H8

The results of the Sobel Test calculation show that the Sobel test statistic value of CMS's influence on SKPK Nagan Raya performance through employee performance is 2.00. This value is greater than 1.96 and is at a significant two-tailed probability value of 0.04 or less than 0.05 . This influence is strengthened by the estimated mediation value of $0.337 \times 0.286=0.096$. This means that employee performance can significantly mediate the effect of CMS on SKPK Nagan Raya performance by $0.096 \%$. In this model, the employee performance is also proved acting as the partial mediator.

\section{CONCLUSION}

The results reveal that SIMDA, CMS, Employee Performance and SKPK Nagan Raya Performance are not at the good levels, SIMDA affects employee performance, CMS affects employee performance, SIMDA affects SKPK Nagan Raya performance, CMS affects SKPK Nagan Raya employee performance, employee performance affects SKPK Nagan Raya performance, SIMDA affects SKPK Nagan Raya performance through employee performance, and CMS affects SKPK Nagan Raya employee performance through employee performance. In the research model, employee performance is also proved to act as the partial mediator. These all findings mean that it has been proven this model can be used as a model for improving organizational performance, especially in SKPK Nagan Raya. Academically this research model contributes to science which reveals that the Role of Management Information Systems which in this study uses SIMDA as a unique subject, as well as CMS, are very capable of influencing employee performance and impacting organizational performance/SKPK Nagan Raya. So that practically the performance improvement of SKPK Nagan Raya can be done through adjustment of SIMDA and CMS so that they can be used effectively and efficiently. In addition, the role of employees in the use of SIMDA and CMS also really needs to be improved so as to be able to 


\section{International Journal of Business Management and Economic Review}

Vol. 4, No. 04; 2021

ISSN: 2581-4664

encourage the improvement of their performance, and also have an impact on improving the performance of SKPK Nagan Raya. The novelty of the research lies in the use of SIMDA as a unique subject, and also the unique CMS as the cash system used by employees of Nagan Raya district, Indonesia. In the future, further researchers can use this research model as the main basis in developing their research by adding other variables such as training and development as well as organizational culture.

\section{REFERENCES}

Al-gharaibeh, S. M. A., \& Malkawi, N. M. M. (2013). The Impact of Management Information Systems on the Performance of Governmental Organizations- Study at Jordanian Ministry of Planning Chair of Management Information Systems Department. International Journal of Business and Social Science. 4(17), 101-109.

Djalil, M. A., Nadirsyah, Yahya, M. Ri., Jalaluddin, \& Ramadhanti, S. V. (2017). The Effect of Used Information Technology, Internal Control, and Regional Accounting System on the Performance of City Governance Agency of Banda Aceh City, Indonesia. BRAND. Broad Research in Accounting, Negotiation, and Distribution, 8(1), 25-37.

Dwiyanto, A. (2012). Reformasi Birokrasi Publik di Indonesia (Cetakan Ke). Yogyakarta: Gadjah Mada University Press.

Fahmi, H. K., Musnadi, S., \& Nadirsyah. (2019). Role Conflict, Self Efficacy, Employees' Performance and Organizational Performance. Journal of Accounting Research, Organization and Economics, 2(1), 31-40. https://doi.org/10.24815/jaroe.v2i1.13013

Gibson, J. L., Ivancevich, J. M., Donnelly, J. H., \& Konopaske, R. (2012). Organization:Behaviour, Structure, Processes (14th ed.). New York: McGraw-Hill.

Gurendrawati, E., Murdayanti, Y., \& Putri, A. G. (2014). The Impact Of Information Technology, Management Accounting System Characteristics, and Locus Of Control To The Managerial Performance In The Telecommunication Service Companies. Review of Integrative Business and Economics Research, 3(3), 357-366.

Hair, J. F., Babin, B. J., Anderson, R. E., \& Black, W. C. (2018). Multivariate Data Analysis (8th Ed.). London: Pearson.

Hartono, B. (2013). Computer Based Management Information System. Jakarta: Rineka Cipta.

Imran, M., Darwanis, \& Arfan, M. (2014). The Effect of Ease of Use of the System, System Benefits and Computer Skills on the Effectiveness of the Regional Financial Management System in the Banda Aceh City Government. Jurnal Administrasi Akuntansi: Program Pascasarjana Unsyiah, 3(4), 54-65.

Jean, R. "Bryan," Sinkovics, R. R., \& Kim, D. (2008). Information technology and organizational performance within international business to business relationships: A review and an integrated conceptual framework. International Marketing Review, 25(5), 563-583. https://doi.org/https://doi.org/10.1108/02651330810904099

Juliansyah, A. (2017). Calculation of Tangible Benefits Application of Cash management system at Regional Banks. Seminar Nasional TIK Dan Ilmu Sosial (SocioTech) 2017, 99-104. Mataram: STMIK Bumigora Mataram.

Lasmaya, S. M. (2016). Influence of HR Information System, Competence and Work Discipline on Employee Performance. Jurnal Ekonomi, Bisnis \& Entrepreneurship, 10(1), 25-43.

Laudon, K. C., \& Laudon, J. P. (2014). Management Information System: Managing The Digital 
International Journal of Business Management and Economic Review

Vol. 4, No. 04; 2021

ISSN: 2581-4664

Firm (13th ed.). United States: Pearson Education Limited.

Mahmudi, M. (2013). Manajemen Kinerja Sektor Publik. Yogyakarta: UPP-STIM YKPN.

Pirade, D., Saleh, A. K., \& Amar, M. Y. (2013). The Influence of the Use of Regional Financial Management Information System (SIPKD) on Employee Performance in Tana Toraja Regency. Jurnal Analisis, 2(2), 183-192.

Sari, I. (2020). Analysis of the Application of the Cash Management System in Regional Financial Management at Pik Pulogadung. Jurnal Perspektif, 18(1), 1-8. https://doi.org/https://doi.org/10.31294/jp.v18i1.6699

Sudriman, A., Muttaqim, Purba, R. A., Wirapraja, A., Abdillah, L. A., Fajrillah, ... Simarmata, J. (2020). Sistem Informasi Manajemen. Surabaya: Yayasan Kita Menulis.

Tyoso, J. S. P. (2016). Management Information System. Yogyakarta: Deepublish. 